\title{
Host, microbial, and pharmacological factors affecting the outcome of suppurative keratitis
}

\author{
DOUGLAS J COSTER AND PAUL R BADENOCH \\ From the Department of Ophthalmology, Flinders Medical Centre, Bedford Park, South Australia
}

\begin{abstract}
SUMMARY A review of 87 cases of microbial keratitis in South Australia was made to determine the factors which influence the outcome of the disease. The preceding pathology and the extent of ulceration at presentation were found to be significant, while the presence of hypopyon was less important. Infection with Pseudomonas aeruginosa was most likely to result in a poor outcome. Most patients had a history of traumatic injury, herpes simplex keratitis, or a corneal graft. The choice of gentamicin and a cephalosporin as appropriate initial therapy in Australia was supported. The results are discussed with reference to current research objectives.
\end{abstract}

Microbial keratitis is a common sight threatening disease which occurs in all parts of the world.' Rational treatment involves identification of the causative agent and institution of specific antimicrobial chemotherapy. This demands clinical suspicion of a microbial cause for keratitis, knowledge of the likely agents in a particular community, reliable microbiological investigation, and the availability of effective antibiotics. Even under optimal conditions treatment is not invariably successful.

In an attempt to identify factors which may affect outcome we have reviewed the course of the disease in patients presenting to the Department of Ophthalmology at Flinders Medical Centre. Although a number of ophthalmologists have been involved, treatment received has been consistent and according to strict protocol.

Flinders Medical Centre is situated in suburban Adelaide. As the Department of Ophthalmology functions both as a primary care facility and a referral centre for the state of South Australia and beyond, the patients described in this study either presented for primary care or were referred by other ophthalmologists. Although management protocols are firmly established and every attempt has been made to keep consistent records, this study has the disadvantages of being retrospective. Such a limited approach, however, is justified in the case of this disease because of the difficulty of carrying out prospective controlled clinical trials.

Correspondence to Professor D J Coster, Department of Ophthalmology, Flinders Medical Centre, Bedford Park, South Australia 5042

\section{Patients and methods}

Between August 1980 and February 1986 material was collected from the corneas of 164 patients for microbiological study. All patients were investigated in whom there was a defect in the corneal epithelium and inflammation in the underlying corneal stroma. Thus both patients in whom microbial infection was strongly suspected as the cause of inflammation and others in whom alternative explanations were possible were similarly tested.

A standardised method of specimen collection was employed. Corneal scrapings were taken in the Eye Clinic or in the ward with an operating microscope or a slit-lamp. Specimens were collected with a platinum spatula. Two horse blood agar plates, a chocolate agar plate, a Sabouraud's agar slope, two glass slides, a cooked meat-glucose broth, and two brain-heart infusion broths supplemented with vitamin $K$, haemin, and nicotinamide adenine dinucleotide (NAD) were inoculated. The Sabouraud's slope was incubated at $30^{\circ} \mathrm{C}$ for up to one month for culture of fungi. The other media were incubated at $37^{\circ} \mathrm{C}$ for two days. One blood plate and the cooked meat broth were incubated anaerobically. The remaining media were incubated in $5 \%$ carbon dioxide/air. The slides were used for Gram and Giemsa stains.

Organisms were identified by standard microbiological methods as given in the Manual of clinical microbiology. ${ }^{2}$ Susceptibility to antimicrobial agents was determined by a modified Kirby-Bauer technique. ${ }^{3}$ A growth was considered significant if 
organisms were seen on microscopy and grew on at least one medium, or if no organisms were seen on microscopy yet growth occurred on at least two media.

\section{Results}

A significant growth of organisms was isolated 87 times from 78 eyes of 76 patients over the $5 \frac{1}{1 / 2}$-year period. There were 50 males and 26 females, and their ages ranged from 14 months to 96 years with two distinct peaks in age distribution, one in early adult life and one in old age (Fig. 1).

Microbial keratitis occurred predominantly in eyes with existing pathology. Predisposing factors were identified in $84 \%$ of the patients (Table 1). Herpes simplex virus (HSV) keratitis was the most common pre-existing disease, these patients having an average age of 59 years. In younger patients (average age 44 years), trauma, including corneal lacerations, abrasions, and foreign bodies, was more common. This difference in corneal status contributed to the two peaks in age distribution. The four cases with exposure ulcers were stroke or comatose patients with inadequate lid closure.

The organism responsible for keratitis comprised about 30 species in 21 genera of bacteria, fungi, and amoebae (Table 2). Bacteria were responsible for 77 cases, fungi for eight, and free-living amoebae for two. All patients were from South Australia except four; three came from Queensland and one from Singapore, all of whom were infected with filamentous fungi. Staphylococcus aureus was the most frequently isolated organism, being responsible by itself for $23 \%$ of the cases. As Staphylococcus epidermidis was isolated alone in 12 cases $(13 \cdot 8 \%)$, staphylococcal species were responsible for more than a third of the infections. An obligate anaerobe,
Table 1 Pathology prior to microbial keratitis

\begin{tabular}{lr}
\hline & No. (\%) of eyes* \\
\hline Trauma & $14(17 \cdot 9)$ \\
HSV keratitis & $12(15 \cdot 4)$ \\
HSV keratitis and corneal graft & $7(9 \cdot 0)$ \\
Corneal graft & $6(7 \cdot 7)$ \\
Exposure ulcer & $4(5 \cdot 1)$ \\
Bullous keratopathy & $3(3 \cdot 8)$ \\
Herpes zoster ophthalmicus & $2(2 \cdot 6)$ \\
Sjögren's syndrome & $2(2 \cdot 6)$ \\
Bowen's procedure to limbus & $1(1 \cdot 3)$ \\
Vernal catarrh & $1(1 \cdot 3)$ \\
Soft contact lens wear & $1(1 \cdot 3)$ \\
Trauma and corneal graft & $1(1 \cdot 3)$ \\
Stevens-Johnson syndrome & $1(1 \cdot 3)$ \\
H. zoster ophthalmicus and corneal graft & $1(1 \cdot 3)$ \\
Systemic lupus erythematosus & $1(1 \cdot 3)$ \\
Lens extraction and IOL implant & $1(1 \cdot 3)$ \\
Multiple myeloma and malnutrition & $1(1 \cdot 3)$ \\
Epithelial dystrophy & $1(1 \cdot 3)$ \\
Prematurity & $1(1 \cdot 3)$ \\
None apparent & $11(14 \cdot 1)$ \\
Not known & $6(7 \cdot 7)$ \\
Total & 78 \\
\hline
\end{tabular}

${ }^{*}$ In 76 patients. Two patients had infections in both eyes; one had Sjögren's syndrome and the other had previous grafts for keratoconus.

Peptostreptococcus anaerobius, was isolated in only one case. Pseudomonas aeruginosa was the most frequently encountered Gram-negative bacillus (GNB), being responsible for $10.3 \%$ of the infections. Two or more organisms were cultured from a cornea on 11 occasions $(12.6 \%)$. In two cases Acanthamoeba species were isolated; one of these patients had splashed wood alcohol into his eye and the other had a three-year history of HSV keratitis.

The Gram stain correlated with the culture result in $58 \%$ of cases (Table 3 ). Of the eight instances

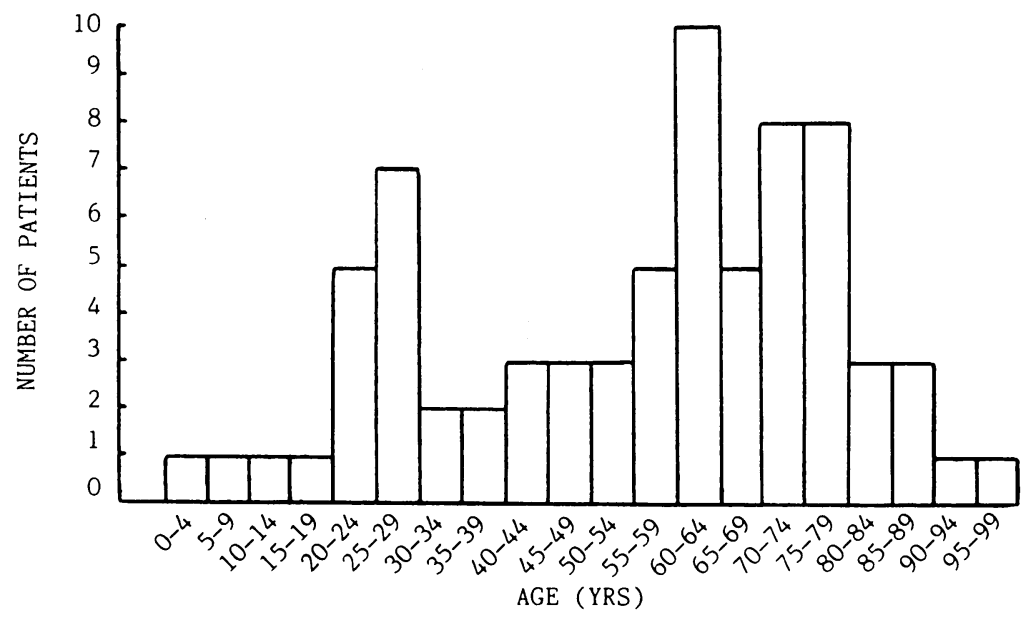

Fig. 1 Age distribution of patients with microbial keratitis. 
Table 2 Organisms isolated from cases of microbial keratitis

\begin{tabular}{|c|c|}
\hline No. 1 & of isolates \\
\hline \multicolumn{2}{|l|}{ Gram-positive cocci } \\
\hline Straphylococcus aureus & $20(23 \cdot 0)$ \\
\hline Staphylococcus epidermidis & $12(13 \cdot 8)$ \\
\hline Streptococcus pneumoniae & $5(5 \cdot 7)$ \\
\hline Viridans streptococci & $4(4 \cdot 6)$ \\
\hline Peptostreptococcus anaerobius & $1(1 \cdot 1)$ \\
\hline Staph. aureus and viridans streptococci & $2(2 \cdot 3)$ \\
\hline Staph. epidermidis and viridans streptococci & $1(1 \cdot 1)$ \\
\hline \multicolumn{2}{|l|}{ Gram-positive bacilli } \\
\hline Corynebacterium spp. & $5(5 \cdot 7)$ \\
\hline \multicolumn{2}{|l|}{ Gram-negative bacilli } \\
\hline Pseudomonas aeruginosa & 9(10·3) \\
\hline Moraxella spp. & $4(4 \cdot 6)$ \\
\hline Haemophilus influenzae & $2(2 \cdot 3)$ \\
\hline Klebsiella oxytoca & $2(2 \cdot 3)$ \\
\hline Proteus mirabilis & $1(1 \cdot 1)$ \\
\hline Serratia marcescens & $1(1 \cdot 1)$ \\
\hline Pseudomonas maltophilia and Achromobacter spp. & $1(1 \cdot 1)$ \\
\hline \multicolumn{2}{|l|}{ Mixed } \\
\hline Staph. epidermidis and Corynebacterium spp. & $2(2 \cdot 3)$ \\
\hline Staph. aureus and Proteus mirabilis & $1(1 \cdot 1)$ \\
\hline Viridans streptococci and Moraxella spp. & $1(1 \cdot 1)$ \\
\hline Viridans streptococci and Corynebacterium spp. & $1(1 \cdot 1)$ \\
\hline Str. pneumoniae, Staph. aureus, and Moraxella & $1(1,1)$ \\
\hline $\begin{array}{l}\text { nonilquejactens } \\
\text { Escherichia coli, Enterobacter cloacae, Hafnia alvei, }\end{array}$ & $1(1 \cdot 1)$ \\
\hline Candida krusei, and Pseudomonas acidovorans & $1(1 \cdot 1)$ \\
\hline \multicolumn{2}{|l|}{ Fungi } \\
\hline Candida albicans & $2(2 \cdot 3)$ \\
\hline Fusarium spp. & $3(3.4)$ \\
\hline Acremonium sp. & $1(1 \cdot 1)$ \\
\hline Alternaria sp. & $1(1 \cdot 1)$ \\
\hline Aspergillus fumigatus & $1(1 \cdot 1)$ \\
\hline \multicolumn{2}{|l|}{ Amoebae } \\
\hline Acanthamoeba spp. & $2(2 \cdot 3)$ \\
\hline Total & 87 \\
\hline
\end{tabular}

where organisms were seen on the smear but did not grow, GNBs were seen six times and Gram-positive cocci (GPC) twice. In three of the six instances the GNBs were large coccobacilli of the Moraxella type.

Data for antimicrobial susceptibility of commonly isolated organisms are shown in Table 4. All isolates of each bacterial species were sensitive to at least two antibiotics. Cephradine was effective in vitro against all isolates except some $P$. aeruginosa. Gentamicin was effective against all isolates except some Streptococcus pneumoniae.
Table 3 Correlation of Gram stain with culture result

\begin{tabular}{lr}
\hline Organisms cultured seen in Gram stain & $45 / 77(58 \cdot 4 \%)$ \\
$\begin{array}{l}\text { Some organisms cultured seen in Gram stain } \\
\text { Organisms not seen }\end{array}$ & $3 / 77(3.9 \%)$ \\
$\begin{array}{l}\text { Other organisms seen (with or without cultured } \\
\text { organisms) }\end{array}$ & $21 / 77(27 \cdot 3 \%)$ \\
\hline
\end{tabular}

After isolation of the organism responsible the patients received specific antimicrobial chemotherapy and most $(\mathbf{7 0} \%)$ also received topical corticosteroids. Corneal transplantation was performed on 18 eyes.

The outcome of treatment of microbial keratitis is given in Table 5. Of the corneal grafts 12 were successful, and one failed owing to allograft rejection. In three cases infection recurred in the grafted eye, but the organisms responsible were other than those which had caused the initial infections. Each of these patients had a history of herpetic ocular infection. All six patients with filamentous fungal infection received a graft; a successful result was achieved in four cases.

Of the 72 eyes for which the outcome was known 13 $(18.1 \%)$ were lost. As well as the recognised pathogens the organisms that contributed to the loss of eyes included Corynebacterium species, Staphylococcus epidermidis, and Streptococcus sanguis type II. In 14 eyes $(19.7 \%)$ there was complete resolution of disease and in $25(35 \cdot 2 \%)$ the infection resolved to useful vision, defined as the hand motion to count fingers range. When the number of cases in which the disease resolved to useful vision or better is added to the number of successful grafts, it can be seen that a good outcome was achieved for $72 \%$ of the eyes.

Treatment was successful for all patients with a history of corneal trauma but for only $42 \%$ of patients with a history of HSV keratitis (Table 6). On $\chi^{2}$ analysis the frequency of a poor outcome for patients with a history of HSV infection was shown to be significantly greater than for those with a history of trauma $(p<0.005)$. In comparison with all other previous pathology the probability that the greater frequency of a poor outcome following HSV infection is due to chance is about $6 \%$.

For 22 patients the outcome of treatment of

Table 4 Percentage of isolates sensitive to various antibiotics

\begin{tabular}{|c|c|c|c|c|c|c|}
\hline & $\begin{array}{l}\text { Staph. } \\
\text { aureus }\end{array}$ & $\begin{array}{l}\text { Staph. } \\
\text { epidermidis }\end{array}$ & $\begin{array}{l}\text { Str. } \\
\text { pneumoniae }\end{array}$ & $\begin{array}{l}\text { Coryne. } \\
\text { spp. }\end{array}$ & $\begin{array}{l}P \text {. } \\
\text { aeruginosa }\end{array}$ & $\begin{array}{l}\text { Moraxella } \\
\text { spp. }\end{array}$ \\
\hline Penicillin & 23 & 0 & 75 & 100 & - & 100 \\
\hline Cephradine & 100 & 100 & 100 & 100 & 33 & 100 \\
\hline Chloramphenicol & 100 & 75 & 100 & 80 & 20 & 100 \\
\hline Gentamicin & 100 & 100 & 33 & 100 & 100 & 100 \\
\hline Tobramycin & - & - & - & - & 100 & - \\
\hline Carbenicillin & - & - & - & - & 100 & - \\
\hline
\end{tabular}


Table 5 Outcome of microbial keratitis

\begin{tabular}{|c|c|}
\hline & No. $(\%)$ of eyes \\
\hline Eye removed & $13(16 \cdot 7)$ \\
\hline Corneal graft - successful & $12(15 \cdot 4)$ \\
\hline -rejected & $1(1 \cdot 3)$ \\
\hline -recurrence of infection & $3(3 \cdot 8)$ \\
\hline Failure of previous graft & $4(5 \cdot 1)$ \\
\hline Recurrence of infection & $2(2 \cdot 6)$ \\
\hline Resolution to useful vision & $23(29 \cdot 5)$ \\
\hline Complete resolution & $14(17 \cdot 9)$ \\
\hline Not known & $6(7 \cdot 7)$ \\
\hline Total & 78 \\
\hline
\end{tabular}

microbial keratitis was not successful. This group had a total of 26 culture-proved infectious episodes in 23 eyes. Additional data are given in Table 7 . Of these patients $70 \%$ had had either HSV keratitis or a previous graft, or both, compared with $38 \%$ overall. The extent of ulceration at presentation was classified as slight if less than $10 \%$ of corneal area was suppurating, moderate if $10-30 \%$ was suppurating, and severe if more than $30 \%$ was involved. The association between a patient presenting with moderate or severe ulceration and a poor outcome was significant $(\mathrm{p}<0.05)$. The presence of hypopyon did not significantly affect outcome. $P$. aeruginosa and mixed infections predominated among the patients having a poor outcome, though the total number of cases is not sufficient to show any significant associations. A poor outcome could not be correlated with the use of inappropriate antibiotics before the antimicrobial sensitivity data became available.

A successful outcome was achieved in $69 \%$ of cases where topical corticosteroid was included in the therapy compared with $78 \%$ where no steroid was given. However, these figures are biased by the consideration that the more severe cases generally received steroid. Infection recurred in $13 \%(7 / 54)$ of
Table 6 Relationship of previous pathology to outcome of microbial keratitis

\begin{tabular}{lll}
\hline & \multicolumn{2}{l}{ No. $(\%)$ of patients } \\
\cline { 2 - 3 } & Trauma & $H S V$ \\
\hline Eye removed & 0 & $4(21 \cdot 1)$ \\
Corneal graft-successful & $2(13 \cdot 3)$ & $4(21 \cdot 1)$ \\
$\quad$-rejected & 0 & $1(5 \cdot 3)$ \\
-recurrence of infection & 0 & $2(10 \cdot 5)$ \\
Failure of previous graft & 0 & $2(10 \cdot 5)$ \\
Recurrence of infection & 0 & $2(5 \cdot 9)$ \\
Resolution to useful vision & $7(46 \cdot 7)$ & $4(21 \cdot 1)$ \\
Complete resolution & $6(40 \cdot 0)$ & 0 \\
\hline
\end{tabular}

patients given steroid compared with $0 \%(0 / 23)$ of patients who did not receive steroid.

\section{Discussion}

The pattern of disease in this series of cases was similar to that seen in other studies from urban communities in temperate climatic zones. ${ }^{46}$ Thus the range of organisms, antimicrobial sensitivity, and predisposing disease were perhaps to be expected. Although there have been no published reports of the outcome of microbial keratitis, less than optimal results are commonly experienced by all ophthalmologists dealing with this condition.

Infection is often responsible for ultimate loss of sight in an eye ravaged over a period of time by chronic relapsing disease consequent upon epithelial disruption and stromal derangement. The frequency of poor outcome of bacterial infection in patients who have chronic herpetic keratitis, and who often have had previous corneal surgery as well, attests to this. It also emphasises the role of the intact epithelium as a primary defence mechanism; corneal infection seldom occurs in otherwise healthy eyes.

Only one case of infection attributable to contact

Table 7 Data on patients with poor outcome*

\begin{tabular}{|c|c|c|c|c|c|c|}
\hline $\begin{array}{l}\text { Average } \\
\text { age (yrs) }\end{array}$ & $\begin{array}{l}\text { Preceding } \\
\text { pathology } \dagger\end{array}$ & $\begin{array}{l}\text { Extent of } \\
\text { ulceration }\end{array}$ & $\begin{array}{l}\text { Hypopyon } \\
\text { presentt }\end{array}$ & Organismst & & $\begin{array}{l}\text { Antibiotics } \\
\text { used }\end{array}$ \\
\hline $60 \cdot 3(53.4)$ & $\begin{array}{lr}\text { HSV and graft } & 26 \\
\text { HSV } & 17 \\
\text { Graft } & 17 \\
\text { Graft and SCL } & 4 \\
\text { H. zoster and graft } & 4 \\
\text { Bullous keratitis } & 4 \\
\text { SLE } & 4 \\
\text { Cat. extract and IOL } & 4 \\
\text { None apparent } & 17\end{array}$ & $\begin{array}{lr}\text { Slight } & 9(43) \\
\text { Moderate } & 57(47) \\
\text { Severe } & 17(10) \\
\text { Unknown } & 17(0)\end{array}$ & $42(24)$ & $\begin{array}{l}\text { P. aeruginosa } \\
\text { Staph. aureus } \\
\text { Coryne. spp. } \\
\text { Str. pneumoniae } \\
\text { Moraxella lacunata } \\
\text { H. influenzae } \\
\text { Serratia marcescens } \\
\text { Str. sanguis II } \\
\text { Staph. epidermidis } \\
\text { Alternaria sp. } \\
\text { Mixed }\end{array}$ & $\begin{array}{l}23(6) \\
19(31) \\
8 \\
8 \\
4 \\
4 \\
4 \\
4 \\
4 \\
4 \\
19(4)\end{array}$ & $\begin{array}{lc}\text { Correct } & 92(80) \\
\text { Incorrect } & 0(0) \\
\text { None used } & 0(16) \\
\text { Unknown } & 8(4)\end{array}$ \\
\hline
\end{tabular}

*Eye removed, graft rejected, recurrence of infection, or failure of a previous graft.

†Expressed as \% of cases. Figures in brackets are for patients with successful outcome.

$\mathrm{SCL}=$ soft contact lens. SLE =systemic lupus erythematosus. $\mathrm{IOL}=$ intraocular lens. 
lens wear was encountered, though perhaps more might have been expected in view of the findings of others. ${ }^{7}$ The patient concerned had been wearing an extended-wear soft lens over an aphakic corneal graft, and had received no routine care for the lens or the eye. Lax aftercare by the ophthalmologist or optometrist and non-compliance on the part of the patient are the major sources of risk to an eye wearing a contact lens. During the period of this study the Contact Lens Clinic at Flinders Medical Centre had as many as 200 patients with extendedwear lenses in its care at any one time.

The management of microbial keratitis was consistent over the five-year period of the study. Initial treatment was based on the Gram stain. If the Gram stain revealed GPCs, a first generation cephalosporin was given topically every hour, either $50 \mathrm{mg} / \mathrm{ml}$ cephradine or, more recently, cephazolin. If GNBs were seen, the patient was treated with $10 \mathrm{mg} / \mathrm{ml}$ gentamicin eye drops every hour. If no organisms were seen, no antimicrobial was given unless the clinical course of events strongly suggested bacterial infection, in which case both gentamicin and cephradine eye drops were administered. In the event of a negative culture, the clinical picture and laboratory results were considered after 24 hours, and the indications for therapy were reviewed after another Gram stain and culture. In all cases the appropriateness of the antimicrobial chemotherapy was reviewed as the results of culture and antimicrobial sensitivity tests came to hand, but with the clinical course always the dominant consideration. Topical corticosteroids were not begun until appropriate antibiotics had been given for 24 hours.

Although most failures to respond to treatment occurred in patients whose eyes were moderately or severely diseased at the time of presentation, either due to the existing predisposing condition or because of late presentation, poor results did occasionally occur unexpectedly. The prognosis may be unfavourable even when a patient presents early, the causative organism is identified, treatment is initiated, and susceptibility of the organism to the antimicrobial agent prescribed is confirmed. A number of factors may account for this. They relate to the interaction of organism, host mediated mechanisms, and pharmacological considerations.

Motivated by the results of this clinical study and the need to identify effective therapeutic regimens, we used a quantitative model in rats to investigate factors influencing the outcome of corneal infection. ${ }^{8}$ Both bacterial and host cells were counted to compare the effectiveness of various treatments. This is necessary because both bacterial and host factors contribute to corneal destruction. ${ }^{9-12}$

The role of topical corticosteroids in microbial keratitis remains controversial. They do not compromise the effectiveness of appropriate antibiotics. ${ }^{812-15}$ However, when used for the treatment of pseudomonas keratitis without effective antimicrobial chemotherapy, the growth of organisms is significantly enhanced. ${ }^{816}$ In addition to replicating organisms both the breakdown products of dead bacteria, for example endotoxin, ${ }^{17}$ and the products of tissue damage ${ }^{18}$ are chemotactic for leucocytes. It would seem that corticosteroids may have an important role in limiting leucocyte recruitment occurring after microbial replication has been halted. In experimental Staph aureus keratitis prednisolone acetate was shown to add significantly to the antiinflammatory effect of cephradine only late in the course of the infection. ${ }^{8}$ Presumably at this time bacterial turnover is less and antimicrobial sensitivity is reduced, or, alternatively, non-replicative elements are responsible for leucocyte recruitment. In either case the suggestion is that in clinical practice little is to be gained by beginning topical corticosteroid therapy before the causative agent has been identified and specific antimicrobial chemotherapy instituted.

The essential element of treatment is delivery of adequate levels of antimicrobial agents to the focus of infection. Animal models are vital for determining the important aspects of drug kinetics in microbial keratitis.

Clinical studies suggest that currently employed doses of most antibiotics, applied topically or subconjunctivally, produce concentrations in the infected cornea that should be effective on the basis of minimum bactericidal concentration (MBC) tests. Carbenicillin, ${ }^{19}$ cephalothin, ${ }^{20}$ gentamicin,${ }^{21}$ and tobramycin ${ }^{22} 23$ reach useful concentrations in the aqueous humour of patients with uninflamed eyes. Since the corneal concentration of an antibiotic is usually at least as high as the aqueous humour concentration, ${ }^{24}$ and the presence of inflammation is known to increase antibiotic penetration into the anterior segment, ${ }^{212526}$ it is likely that the peak corneal concentration obtained in patients with suppurative keratitis is well above the MBCs of common pathogens. However, using rats we have found with cephradine that a 'passing through' effect can occur after topical administration on to an inflamed eye in which the tissue concentration fell to sub-MBC levels more rapidly than it would do in a normal eye. ${ }^{26}$ This suggests that applications may need to be made more frequently than is usual.

An MBC must be considered only as a guide to the likely susceptibility of an organism to an antibiotic in vivo. It is determined with the use of organisms in logarithmic growth. However, in established infections the rate of cell turnover is less, so that the 
in-vivo $\mathrm{MBC}$ is in effect increased. We have found that the ratio of the antibiotic concentration required for $99 \%$ killing in the cornea to that in vitro is as high as 70:1 (presented at the Ocular Microbiology and Immunology Group Meeting, Atlanta, 1984).

Helpful as these animal studies are in increasing our understanding of microbial keratitis and its treatment, and difficult as it is to conduct clinical trials with a condition so diverse in its features, it is nevertheless necessary to pursue these trials if we are to improve our treatment of this important condition.

The authors thank Wendy Laffer for editorial assistance and Judy Stone for preparing the manuscript.

\section{References}

1 World Health Organisation. Data on blindness throughout the world. WHO Chron 1979; 33: 275-83.

2 Lennette EH, Balows A, Hausler WJ, Shadomy HJ, eds. Manual of clinical microbiology. Washington, DC: American Society for Microbiology, 1985.

3 Performance standards for antimicrobial disc susceptibility tests. 3rd ed. Villanova, Pennsylvania: National Committee for Clinical Laboratory Standards, 1984.

4 Jones DB. A plan for antimicrobial therapy in bacterial keratitis. Ophthalmology 1975; 79: 95-103.

5 Asbell P, Stenson S. Ulcerative keratitis: survey of 30 years' laboratory experience. Arch Ophthalmol 1982; 100: 77-80.

6 Musch DC, Sugar A, Meyer RF. Demographic and predisposing factors in corneal ulceration. Arch Ophthalmol 1983; 101: 1545-8.

7 Leisegang TJ, Forster RK. Spectrum of microbial keratitis in South Florida. Am J Ophthalmol 1980; 90: 38-47.

8 Badenoch PR, Hay GJ, McDonald PJ, Coster DJ. A rat model of bacterial keratitis: effect of antibiotics and corticosteroid. Arch Ophthalmol 1985; 103: 718-22.

9 Johnson MK, Allen JH. Ocular toxin of the pneumococcus. Am J Ophthalmol 1971; 72: 175-80.

10 Kessler E, Mondino B, Brown SI. The corneal response to Pseudomonas aeruginosa: histopathological and enzymatic characterisation. Invest Ophthalmol Vis Sci 1977; 16: 116-25.

11 Berman M. Regulation of collagenase: therapeutic considerations. Trans Ophthalmol Soc UK 1978; 98: 397-405.
12 Foster CS, Zelt RP, Mai-Phan T, Kenyon KR. Immunosuppression and selective inflammatory cell depletion. Arch Ophthalmol 1982; 100: $1820-4$.

13 Bohigian GM, Foster CS. Treatment of Pseudomonas keratitis in the rabbit with antibiotic-steroid combinations. Invest Ophthalmol Vis Sci 1977; 16: 553-6.

14 Davis SD, Sarff LD, Hyndiuk RA. Corticosteroid in experimentally induced Pseudomonas keratitis: failure of prednisolone to impair the efficacy of tobramycin and carbenicillin therapy. Arch Ophthalmol 1978; 96: 126-8.

15 Leibowitz HM, Kupferman A. Topically administered corticosteroids: effect on antibiotic-treated bacterial keratitis. Arch Ophthalmol 1980; 98: 1287-90.

16 Smolin G, Okumoto M, Leong-Sit L. Combined gentamicintobramycin-corticosteroid treatment. II. Effect on gentamicinresistant pseudomonas keratitis. Arch Ophthalmol 1980; 98: 473-4.

17 Howes EL, Cruse VK, Kwok MT. Mononuclear cells in the corneal response to endotoxin. Invest Ophthalmol Vis Sci 1982; 22: 494-501.

18 Ryan GB, Majno G. Inflammation. Kalamazoo: Upjohn, 1977: 42-57.

19 Boyle GL, Gwon AE, Zinn KM, Leopold IH. Intraocular penetration of carbenicillin after subconjunctival injection in man. Am J Ophthalmol 1972; 73: 754-9.

20 Boyle GL, Abel R, Lazachek GW, Leopold IH. Intraocular penetration of sodium cephalothin in man after subconjunctival injection. Am J Ophthalmol 1972; 74: 868-74.

21 Ellerhorst B, Golden B, Jarudi N. Ocular penetration of topically applied gentamicin. Arch Ophthalmol 1975; 93: 371-8.

22 Petounis A, Papapanos G, Karageorgiou-Makromihelaki C. Penetration of tobramycin sulphate into the human eye. $\mathrm{Br} \mathrm{J}$ Ophthalmol 1978; 62: 660-2.

23 Gordon TB, Cunningham RD. Tobramycin levels in aqueous humor after subconjunctival injection in humans. $A m$ J Ophthalmol 1982; 93: 107-10.

24 Maurice DM, Mishima S. Ocular pharmacokinetics. In: Sears ML, ed. Handbook of experimental pharmacology: Pharmacology of the Eye. Berlin: Springer. 1984: 69: 19116.

25 Benson $\mathrm{H}$. Permeability of the cornea to topically applied drugs. Arch Ophthalmol 1974; 91: 313-27.

26 Badenoch PR, McDonald PJ, Coster DJ. Effect of inflammation on antibiotic penetration into the anterior segment of the rat eye. Invest Ophthalmol Vis Sci 1986; 27: 958-65. 